\title{
Determinants of Crossbreeding Practices by Cattle Farmers in South Benin, West Africa: Implications for the Sustainable Use of the Indigenous Lagune Cattle Population
}

\author{
Maurice Cossi Ahozonlin ${ }^{1}$, Ivan Bossima Koura ${ }^{2} \&$ Luc Hippolyte Dossa $^{1}$ \\ ${ }^{1}$ Ecole des Sciences et Techniques de Production Animale, Faculté des Sciences Agronomiques, Université \\ d'Abomey-Calavi, 03 Boîte Postale 2819 Cotonou, Bénin \\ ${ }^{2}$ Ecole de Gestion et d'Exploitation des Systèmes d'Elevage, Université Nationale d'Agriculture. BP 43, Kétou, \\ Bénin \\ Correspondence: Luc Hippolyte Dossa, Ecole des Sciences et Techniques de Production Animale, Faculté des \\ Sciences Agronomiques, Université d'Abomey-Calavi, 03 Boîte Postale 2819 Cotonou, Bénin. Tel: \\ 229-6717-3511. E-mail: hippolyte.dossa@fsa.uac.bj; dolhip@yahoo.com
}

Received: February 26, 2019 Accepted: March 22, 2019 Online Published: April 13, 2019

doi:10.5539/sar.v8n2p101 URL: https://doi.org/10.5539/sar.v8n2p101

\begin{abstract}
While it is widely acknowledged that the small-sized West African Shorthorn taurine Lagune cattle is being increasingly crossbred with and replaced by large-sized zebus, little is known about the factors that influence farmers' crossbreeding decisions and selection practices. But this information is necessary for the development of strategies towards a rationale use and conservation of this unique African genetic resource. To fill this knowledge gap, we conducted, between September and November 2016, a questionnaire survey in the belt of this breed in South Benin. One hundred seventy-three cattle farms were surveyed. The binomial logistic regression approach was used to predict the likelihood of a Lagune cattle farmer to be willing to introduce zebus in his herd. The herds were composed of either Lagune only (82.1\%), zebu only (4.0\%), crossbred Lagune $\mathrm{x}$ zebu (1.2\%), Lagune and zebu (9.2\%) or Lagune and crossbred Lagune x zebu (3.5\%). The low productivity of the Lagune cattle and the market demand for large-sized animals were the main farmers' motivations for crossbreeding. Farmers raising large herds of Lagune cattle under control mating system were more likely to adopt crossbreeding. The risk of dilution of the Lagune breed could be reduced by increasing awareness among farmers, improving their technical skills in herd management and empowering them to develop legal institutions, by-laws and collective actions for sustainable breed management. Farmers who have already adopted crossbreeding should be provided with appropriate services and technical assistance, whereas breed conservation initiatives should mainly focus on small purebred herds kept under control mating.
\end{abstract}

Keywords: conservation, local breed, management practices, smallholder, sustainable use

\section{Introduction}

African cattle genetic resources are composed of taurine (Bos taurus), zebus (Bos indicus) and diverse products derived from their crossbreeding (Mwai, Hanotte, Kwon, \& Cho, 2015). These genetic resources have developed in harsh environmental conditions to which they have adapted. They are mostly characterized by various genetic traits, namely, their resistance to diseases and drought, their ability to walk, their capacity to survive on poor pastures, and their fertility. They play a vital role in food security and poverty reduction in pastoral and agropastoral communities (Duteurtre, 2007), and are therefore essential for the sustainability of livestock production systems, especially in the current context of rapid urbanization, shrinkage grazing resources and diseases outbreaks. Unfortunately, this genetic wealth, which is still insufficiently characterized, is increasingly threatened by genetic dilution. This is particularly true of the Lagune cattle populations of Benin (Rege \& Tawah, 1999; Felius et al., 2014). This breed, a Dwarf West African Shorthorn type, is one of the smallest cattle breeds in the world (Rege \& Tawah, 1999; Blench, 1999; Adebambo, 2001). Known for its adaptability to humid and subhumid regions and for its resistance to parasitic diseases, it is traditionally kept in smallholding herds in the low Oueme Valley region, its belt in south Benin. Its population size, estimated to 37,000 in 2001 (Ministère de l'Agriculture de l'Élevage et de la Pêche [MAEP], 2002), has sharply decreased in the last decade. Currently, 
there is no data about its effective population size (Porter, Alderson, Hall, \& Sponenberg, 2016). But it is generally accepted that this smallholder's breed is threatened in its belt, mostly because of increasing poorly controlled crossbreeding with zebus, inappropriate husbandry practices and changes in farmers' breeding strategies (Kamuanga, Somda, Sanon, \& Kagoné, 2008). Several authors (Ayantunde, Asse, Said, \& Fall, 2014; Mopaté, Kamuanga, Hamadou, \& Kaboré-Zoungrana, 2014; Ndiaye et al., 2015) have pointed out transhumance, a seasonal and cyclical movement of herds from the driest to the most humid and sub-humid areas, as another important source of genetic mixtures and risk of dilution of the West African Shorthorn cattle populations. Indeed, transhumance has contributed to the expansion of zebu breeds in areas formerly heavily colonized by tsetse flies and known as natural habitats for taurine breeds (Blench, 1999; Basset \& Turner, 2007).

Crossbreeding in smallholder systems is never done systematically (Wollny, 2003; Sokouri et al., 2009; Leroy, Baumung, Boettcher, Scherf, \& Hoffmann, 2016; Wilson, 2018). Yet, despite its rise among Lagune cattle farmers in West Africa and in Benin especially, little research attention has been devoted to farmers' motivations for this practice. But the understanding of the factors underlying their breeding decisions is very crucial for the design of appropriate supportive policies and breed improvement programs. Hence, the main objective of this study was to understand the determinants of crossbreeding practices by Lagune cattle farmers in South Benin. We hypothesized that farmers' motivations for crossbreeding Lagune cattle with zebus vary according to location, being greater in locations under higher influence of transhumance.

\section{Material and Methods}

\subsection{Study Area}

This study was carried out in the Oueme valley, a region considered as the "cradle" of the West African Shorthorn Lagune cattle breed. This region, which includes the localities of Aguegues, Dangbo, Adjohoun and Bonou, regularly hosts local and foreign transhumant cattle herds during the dry season. For the purpose of this study, we adopted the subdivision of this region in three zones according to the influence of transhumance as suggested by Alimi, Biaou, \& Egboou (2015): 1) zone under weak influence (WIZ), which includes Adjohoun and Dangbo and accommodates transhumant herds but in intermittent way; 2) zone under strong influence (SIZ) which includes Bonou and is an important zone of transit and/or regular destination of transhumant herds; and 3) zone of no influence (NIZ) which includes only Aguegues (Figure 1).

The Oueme valley has a subequatorial climate with four seasons: a long dry season from December to March, a long rainy season from April to July, a short dry season from August to September and a short rainy season from October to November. The annual precipitation averages $1400 \mathrm{~mm}$. The temperatures range from 25 to $30^{\circ} \mathrm{C}$. There are two main types of soil: sandy and alluvial soils. The latter are the most fertile but are flooded for 6 months in the year, usually from June to November (Pazou et al., 2013). The main natural vegetation consists of grassy savanna, shrubby and swampy forests, and grasslands (Ali, Odjoubere, Tente, \& Sinsin, 2014; Alimi et al., 2015). Agriculture is the main economic activity with staple crops such as maize, cowpea, cassava, sweet potato, vegetable crops (chili pepper, okra, sweet pepper, and tomatoes), and cash crops such oil palm and coconut palm. Other economic activities include trade, food transformation, fishing and fish breeding, ruminant livestock (sheep, goats and cattle) farming, small stock (poultry and pig) farming and handicraft (Alimi et al., 2015). 


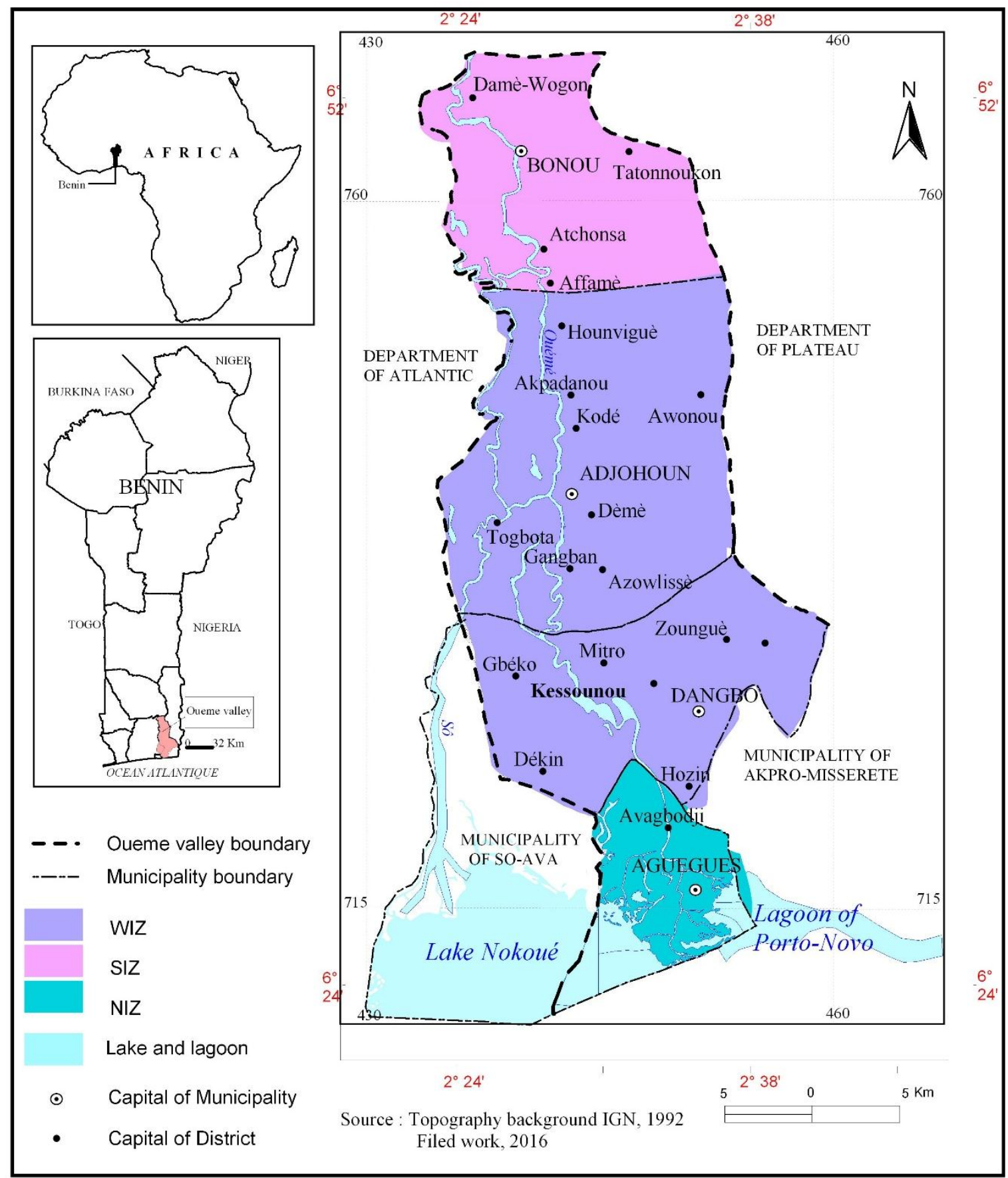

Figure 1. Map of study area showing the zones with weak (WIZ), strong (SIZ) and no influence (NIZ) of transhumance

\subsection{Sampling and Data Collection}

In each location, focus groups discussions were organized with officers of local extension services responsible for livestock production, and with other key resource persons to rank and select villages to survey according to the importance of cattle farming and the number of cattle farmers. In each selected village, only farmers who owned at least three cattle and willing to participate in the survey were included in this study. A total of 173 farmers (97 in WIZ, 36 in SIZ and 40 in the NIZ) was interviewed, between September and November 2016, using a semi-structured questionnaire which contained questions related to the socio-economic characteristics of the respondents, the characteristics of their cattle farms, their perceptions about cattle breeds, their motivations for and practices of selection and crossbreeding. The geographical position of each cattle farm was 
georeferenced using a GPS Garmin-30 device (Etrex vista TM) and their distances to the nearest cattle market recorded.

\subsection{Data Analysis}

All statistical analyses were performed using the Statistical Package for Social Sciences SPSS-PC Version 20. Cross tabulations with calculation of Chi-square $\left(\chi^{2}\right)$ statistics were used to explore the nominal variables characterizing the cattle system across the different zones. Mean and standard deviations of continuous variables were also calculated and compared across zones using the non-parametric Kruskal-Wallis independent sample test. Subsequently, a binary logistic regression analysis was performed on a set of categorical and continuous variables to identify possible significant factors that influence a farmer's desire to introduce zebu animals into his herd of Lagune cattle. This logistic regression model makes it possible to predict the membership of a predefined class from a series of descriptors. As a general rule, the dependent variable is binary or dichotomous and can be 1 (group member) with a probability of success of $\mathrm{P}$ or 0 (non-member) with a failure probability of 1-P. The relationship between the dependent and independent variables is not a linear function. Instead, the logistic regression function is used, which is the logit transformation of y:

$$
\text { Logit }[\mathrm{y}(\mathrm{x})]=\alpha+\beta_{1} x_{1}+\beta_{2} x_{2}+\ldots \ldots+\beta_{i} x_{i}
$$

Where $\alpha=$ the constant of the equation and $\beta=$ the coefficient of the independent variables.

In the logistic regression procedure used, the analysis begins with a complete model that includes all variables. Then, variables that are not useful for predicting the dependent variable are eliminated from the model. The analysis is completed when no variables can be eliminated from the model. The signs of the coefficients indicate the direction of the relationship between the independent variables and the dependent variable.

\section{Results}

\subsection{Characteristics of Cattle Farmers and Cattle Herds in the Oueme Valley}

The socio-economic characteristics of the surveyed Lagune cattle farmers are presented in Table 1. Irrespective of location, the cattle farmers were mostly (93.6\%) men. Their average age was $45.5 \pm 10.16$ years and crop farming was their main activity. Without any significant difference among locations, they had an average of $16.6 \pm 12.26$ years of experience in cattle farming. The average cattle herd size was 8 heads, though about $44 \%$ of surveyed herds had between 5 and 10 animals.

Table 1. Socio-economic characteristics of cattle farmers in the Oueme Valley

\begin{tabular}{|c|c|c|c|c|c|c|}
\hline \multirow[t]{3}{*}{ Variables } & \multirow[t]{3}{*}{ Overall $(n=173)$} & \multicolumn{3}{|c|}{ Zones according to influence of transhumance } & \multirow[t]{3}{*}{$\chi^{2}$} & \multirow[t]{3}{*}{ p-value } \\
\hline & & $\begin{array}{l}\text { WIZ } \\
(\mathrm{n}=97)\end{array}$ & $\begin{array}{l}\text { SIZ } \\
(\mathrm{n}=36)\end{array}$ & $\begin{array}{l}\text { NIZ } \\
(\mathrm{n}=40)\end{array}$ & & \\
\hline & & \multicolumn{3}{|c|}{ Percentage of responses (\%) } & & \\
\hline Sex & & & & & 0.131 & 0.936 \\
\hline Male & 93.6 & 93.8 & 94.4 & 92.5 & & \\
\hline Female & 6.4 & 6.2 & 5.6 & 7.5 & & \\
\hline Main activity & & & & & 8.451 & 0.038 \\
\hline Crop farming & 94.2 & 97.8 & 96.7 & 94.6 & & \\
\hline Cattle farming & 5.8 & 2.2 & 3.3 & 5.4 & & \\
\hline \multicolumn{7}{|c|}{ Means \pm standard deviation } \\
\hline Age (years) & $45.5 \pm 10.16$ & $42.2 \pm 10.33$ & $48.3 \pm 11.14$ & $45.8 \pm 9.03$ & & 0.175 \\
\hline Experience (years) & $16.6 \pm 12.26$ & $17.2 \pm 12.21$ & $14.9 \pm 8.78$ & $16.6 \pm 14.95$ & & 0.733 \\
\hline Herd size (n) & $7.8 \pm 8.85$ & $7.8 \pm 5.41$ & $6.9 \pm 6.15$ & $8.8 \pm 15.43$ & & 0.331 \\
\hline
\end{tabular}

Note. WIZ= weak influence zone; SIZ= strong influence zone and $\mathrm{NIZ}=$ no influence zone.

\subsection{Breeds and Reproductive Management Practices}

Most of surveyed herds (87.3\%) were composed of one cattle breed (Table 2). In addition to Lagune breed, zebus and different crossbreeds (zebu x Lagune) were observed. About $53.8 \%$ of farmers reported that they control mating. However significant differences were observed across locations (Table 2). The highest proportion $(82.5 \%)$ of farmers who were practicing free mating was observed in the zone free of transhumance (NIZ) and the lowest (34.0\%) in the zone under weak influence of transhumance (WIZ). 
Table 2. Distribution (\% of herds) of cattle genotypes across zones in the Oueme Valley

\begin{tabular}{|c|c|c|c|c|c|c|}
\hline \multirow[t]{2}{*}{ Variables } & \multicolumn{6}{|c|}{ Zones according to influence of transhumance } \\
\hline & Overall $(n=173)$ & $\begin{array}{l}\text { WIZ } \\
(\mathrm{n}=97)\end{array}$ & $\begin{array}{l}\text { SIZ } \\
(\mathrm{n}=36)\end{array}$ & $\begin{array}{l}\text { NIZ } \\
(\mathrm{n}=40)\end{array}$ & $\chi^{2}$ & P-value \\
\hline \multicolumn{7}{|c|}{ Number of genotypes per herd } \\
\hline One & 87.3 & 88.7 & 86.1 & 85.0 & 0.398 & 0.820 \\
\hline Two and more & 12.7 & 11.3 & 13.9 & 15.0 & & \\
\hline \multicolumn{7}{|l|}{ Genotypes } \\
\hline Lagune $(L)$ & 82.1 & 79.4 & 86.1 & 85.0 & 8.445 & 0.391 \\
\hline Zebu $(Z)$ & 4.0 & 7.2 & 0.0 & 0.0 & & \\
\hline Crossbreed (LxZ) & 1.2 & 2.1 & 0.0 & 0.0 & & \\
\hline Mix of $L$ and $Z$ & 9.2 & 8.2 & 8.3 & 12.5 & & \\
\hline Mix of $L$ and $L x Z$ & 3.5 & 3.1 & 5.6 & 2.5 & & \\
\hline \multicolumn{7}{|l|}{ Mode of mating } \\
\hline Controlled & 53.8 & 66.0 & 61.1 & 17.5 & 39.341 & 0.001 \\
\hline Free & 46.2 & 34.0 & 38.9 & 82.5 & & \\
\hline
\end{tabular}

Note. $\mathrm{WIZ}=$ weak influence zone; $\mathrm{SIZ}=$ strong influence zone and $\mathrm{NIZ}=$ no influence zone.

\subsection{Farmers' Motivations for Animal Selection and Criteria Used}

Without any significant differences across zones, most (90\%) of the farmers reported that they select animals within their herds for breeding purposes. Table 3 shows stated farmers' motivations for selection and criteria used. Animals from both sexes are selected for improving herd's productivity. Body conformation was the mostly reported selection criterion either for male or female animal. The same criteria were used when selecting heifers to replace breeding females culled either for reproductive failure, diseases or old age. Replacement heifers were obtained either from the same herd $(55.5 \%)$, neighboring herds $(40.4 \%)$ or purchased from livestock markets $(4.1 \%)$.

Table 3. Motivations for selecting reproductive animals and criteria used

\begin{tabular}{lcc}
\hline Variables & $\begin{array}{c}\text { Selection of male } \\
(\mathrm{n}=74 \text { respondents })\end{array}$ & $\begin{array}{c}\text { Selection of female } \\
(\mathrm{n}=154 \text { respondents })\end{array}$ \\
\cline { 2 - 3 } & \multicolumn{2}{c}{ Frequency of responses (\%) } \\
\hline Motivations & 89.0 & 87.3 \\
$\quad$ Improvement of herd productivity & 20.5 & 19.7 \\
$\quad$ Breed conservation & & \\
Criteria & 12.3 & 9.3 \\
$\quad$ Rusticity & 13.7 & 5.3 \\
Rapid growth & 12.5 & 19.2 \\
Disease resistance & 88.9 & 78.8 \\
General conformation & 0.0 & 4.0 \\
Coat color & 5.6 & 21.9 \\
Performance of parent & & \\
\hline
\end{tabular}

\subsection{Farmers' Breed Preference and Perceptions of Threats to Lagune Breed}

Except zebu cattle keepers, farmers in all zones reported that they do not milk the lactating cows in their herds. In addition, most $(69.3 \%)$ of the farmers, mentioned their preference for Lagune cattle than for zebus $(20.0 \%$ respondents), while the remaining farmers were undecided. Furthermore, about $77 \%$ of the farmers admitted that the Lagune cattle breed was threatened and identified their own lack of technicity, herd mismanagement (absence of health treatments, early disposal of Lagune bulls) and crossbreeding by/replacement with zebus, as the main threats (Table 4$)$. The latter threat was significantly $(\mathrm{p}<0.001)$ mentioned by a higher proportion of farmers in the zone without influence of transhumance than in the two other zones. 
Table 4. Farmers' perceptions of the threats to Lagune breed in the Oueme valley ( $\mathrm{n}=164)$

\begin{tabular}{|c|c|c|c|c|c|c|}
\hline \multirow{3}{*}{ Threats } & \multirow{2}{*}{$\begin{array}{l}\text { Overall } \\
(\mathrm{n}=164)\end{array}$} & \multicolumn{3}{|c|}{$\begin{array}{l}\text { Zones according to influence of } \\
\text { transhumance }\end{array}$} & \multirow[t]{2}{*}{$\chi^{2}$} & \multirow[t]{2}{*}{ Significance } \\
\hline & & $\begin{array}{c}\text { WIZ } \\
(\mathrm{n}=91)\end{array}$ & $\begin{array}{c}\mathrm{SIZ} \\
(\mathrm{n}=32)\end{array}$ & $\begin{array}{c}\text { NIZ } \\
(n=38)\end{array}$ & & \\
\hline & \multicolumn{6}{|c|}{ Percentage of responses $(\%)$} \\
\hline $\begin{array}{l}\text { Crossbreeding by/ } \\
\text { replacement with zebus }\end{array}$ & 35.3 & 21.6 & 30.6 & 72.5 & 32.522 & 0.001 \\
\hline Farmers' lack of technical skills & 42.2 & 41.2 & 50.0 & 37.5 & 1.297 & 0.523 \\
\hline Urbanization & 2.3 & 4.1 & 0.0 & 0.0 & 3.208 & 0.201 \\
\hline Herd mismanagement & 27.2 & 27.8 & 36.1 & 17.5 & 5.058 & 0.080 \\
\hline Lack of pasture & 11.6 & 15.5 & 2.8 & 10.0 & 4.575 & 0.206 \\
\hline
\end{tabular}

Note. $\mathrm{WIZ}=$ weak influence; $\mathrm{SIZ}=$ strong influence and $\mathrm{NIZ}=$ no influence; Multiple responses were allowed

\subsection{Farmers' Motivations for Crossbreeding and/or Replacement of Lagune Cattle by Zebus}

Regardless of zone, $54.5 \%$ of purebred Lagune cattle farmers were willing to introduce zebu breed in their herds. The rapid growth $(64.4 \%)$ and large size $(23.0 \%)$ of zebu breeds, but also their perceived higher productivity and market demand $(83.9 \%)$, were the main motivation for zebus. In contrast, the main reasons given by farmers who did not express the desire of zebu animals were the difficulty of raising them (85.7\%), their lack of docility (21.7\%), their high sensitivity to diseases mainly to trypanosomiasis (17.6\%) and the need to move them every day for water and grazing $(17.4 \%)$. Furthermore, the latter group of farmers had significantly $(\mathrm{p} \leq 0.05)$ smaller cattle herd sizes (4.8 against 9.2 heads) and lower experience in cattle breeding (12.9 years) than those who wished to introduce zebu breed (19.4 years).

\subsection{Factors Determining Farmers' Willingness to Crossbreeding/Replacement of Lagune Cattle by Zebus}

The decision by a Lagune cattle farmer to introduce or not a zebu breed in his herd varied significantly $(\mathrm{p} \leq 0.05)$ according to his herd size, his experience in cattle keeping and the mating mode he practices. Results of the logistic regression are presented in Table 6 and show that the probability of adoption of zebu as herd improvement strategy by a Lagune cattle farmer increases with its herd size and the practice of controlled mating in the farm. The $\mathrm{e}^{\beta}$ values indicated that when the herd size increases by 1 head, the odds ratio increases by 1.287 times implying that farmers are 1.287 times more likely to introduce zebu as a strategy to improve herd productivity. This odds ratio is 2.964 times greater when mating is controlled. A test of the full model against a constant only model was statistically significant, indicating that the predictors (herd size and mating mode) as a set, reliably distinguished between adopters and non-adopters of zebu as strategy of improving herd productivity $(\chi 2=27.293, p<0.001, d f=2)$. The non-significance of Hosmer and Lemeshow test $(p \geq 0.05)$ confirmed the validity of the regression model. The overall prediction success rate was $66.9 \%$ (69.0\% for adopters vs. $64.3 \%$ for non-adopters of zebu).

Table 6. Factors determining Lagune cattle farmers' desire to introduce zebu into their Lagune cattle herds $(n=154)$

\begin{tabular}{lllllll}
\hline Predictors & $\beta$ (coef) & S.E of $\beta$ & Wald's $\chi^{2}$ & df & $\mathrm{p}$ & Odds ratio \\
\hline Constant & -1.836 & 0.492 & 13.905 & 1 & 0.001 & 0.159 \\
Herd size & 0.252 & 0.075 & 11.474 & 1 & 0.001 & 1.287 \\
Breeder's experience & 0.016 & 0.019 & 0.707 & 1 & 0.400 & 1.017 \\
Control mating (1) & 1.087 & 0.395 & 7.549 & 1 & 0.006 & 2.964 \\
Test & & & $\chi^{2}$ & df & p & \\
Overall model evaluation (model $\left.\chi^{2}\right)$ & 27.293 & 2 & 0.001 & \\
Hosmer and Lemeshow Test & & 9.033 & 7 & 0.250 & \\
-2loglikelihood = 176.882 & & & & & \\
Cox and Snell $\mathrm{R}^{2}=0.205$ & & & & & \\
Nagelkerke $\mathrm{R}^{2}=0.274$ & & & & & \\
\hline
\end{tabular}

\section{Discussion}

This study was designed to determine the effect of transhumance on farmers' motivations for crossbreeding and/or substitution of Lagune cattle with zebu breeds. The bivariate analysis in this study did not show a 
significant association between these two variables.

Contrary to expectations, there were no surveyed herds composed of zebus only in the zone under strong influence of transhumance. Furthermore, in contrast to most $(82 \%)$ herds surveyed in the zone free of transhumance, two-third of cattle herds in the two other zones under weak and strong influence of transhumance were kept under natural controlled mating system. Mating was controlled either by tethering the animals, limiting their movements, or by keeping only cows/heifers, or by keeping a unique bull in the herd. This implies that, unlike in herds where several reproductive males are kept together with cows/heifers, a specific bull is chosen by the farmer to breed the cows /heifers. However, whenever a zebu bull is maintained in a Lagune cattle herd, the farmer tends to mate it with all cows present in the herd. These results are in accordance with findings of Sokouri et al. (2009) in the northern region of Côte d'Ivoire and of Traoré, Markemann, Reiber, \& Piepho (2017) in South Mali.

The results of the logistic regression analysis showed a significant and positive effect of the practice of controlled mating on farmer's desire to introduce zebus in his herd. Holding other variables constant, the probability of a farmer to crossbreed/replace the Lagune cattle in his herd with zebus is about 2.964 times greater when he controls mating. This result further supports the idea that most crossbreeding and replacement of Lagune cattle with zebus in South Benin are not uncontrolled/indiscriminate, but purposively done by Lagune cattle farmers, irrespective of their geographic positions, to achieve their production objectives.

Another important finding is the positive and significant coefficient of herd size in the logistic regression analysis (Table 6), suggesting that for one-unit increase in the number of cattle owned the probability of a Lagune cattle farmer's desire to introduce zebus in his herd increases 1.287 times, other factors held constant. This result might be explained by the fact that as herd size increases, farmers' production objectives change and cattle farming increasingly shifts from a secondary and subsistence to a market-oriented activity. Hence, by crossbreeding and/or replacing the small sized taurine breed with zebus, farmers express their desire to intensify their production. The advantages, challenges and opportunities of crossbreeding cattle in the tropics are well-documented (Roschinsky, Kluszczynska, Sölkner, Puskur, \& Wurzinger, 2015; Leroy et al., 2016; Wilson, 2018). The main advantage of crossing zebus with the Lagune taurine cattle is to capitalize on the complementary of the two types of cattle: the resistance to disease, and more specifically to trypanosomiasis, for Lagune cattle and the high growth performances and market price for the zebu cattle which is sensible to trypanosomiasis. However, as in most smallhoder production systems context worldwide, the sustainability of crossbreeding is challenged by the lack by farmers of the skills needed to improve their management practices in order to make use of the animals' higher genetic potential (Leroy et al., 2016). This lack of skills associated with herd mismanagement was recognized and expressed by more than two-third of the farmers surveyed in this study as the main threat to Lagune cattle. Another important constraint to the sustainability of the observed crossbreeding practices is the lack of any formal participatory selection and/or breeding program to ensure a continued availability of purebred Lagune cattle.

The practice of cow selection for reproduction as reported by the majority of Lagune farmers surveyed in this study is a critical strategy to help reduce inbreeding effects in small herds (Mwambene, Katule, Chenyambuga, \& Mwakilembe, 2012), and to conserve the Lagune breed. The animal's general conformation and growth, regardless of its sex, are the most important selection criteria used by Lagune farmers. The same criteria were observed among local Ankole cattle farmers in Uganda, Burundi, Rwanda, and Tanzania (Wurzinger et al., 2006), among Sheko cattle farmers in Ethiopia (Desta, Ayalew, \& Hedge, 2011), among breeders of the local Ankole breed in Uganda (Kugonza, Nabasirye, Hanotte, Mpairwe, \& Okeyo, 2012), and among breeders of the local Kereyu Sanga breed in Ethiopia (Garoma, Ayalew, \& Hedge, 2013). These two criteria are not difficult to measure and could be used as the basis for the development of a participatory performance recording system, paving the way to the implementation of a participatory selection program for the Lagune cattle.

\section{Conclusion and Policy Implications}

While crossbreeding will likely continue among Lagune cattle farmers, their breeding strategies have to be adjusted because a continued availability of purebred animals is needed to ensure sustainable crossbreeding strategies. Hence, there is an urgent need to prevent the further genetic erosion of the Lagune breed and promote its rationale use and conservation through the development and implementation of appropriate legal, local as well as public institutions and adequate breeding policies. Such policies should be designed to:

- Enhance farmers' technical skills through tailored-made trainings on all aspects of production, including improved herd management strategies; 
- Promote the creation and organization of associations of farmers with purebred Lagune cattle, especially those owning small herd sizes, and empower them through the establishment of breed performances recording, selection and conservation schemes;

- Provide supportive information and services to farmers who have adopted crossbreeding. These services should include the development of sound crossbreeding plans that exploit both heterosis and complementary of the Lagune and zebus breeds and match with available feed resources, environmental conditions, management levels and markets.

\section{Acknowledgments}

The authors would like to thank the German Volkswagen Foundation, which financially supported this study through the Grant Number: Az 89367. The authors are also grateful to the cattle farmers for their valuable help and collaboration during the field work.

\section{References}

Adebambo, O. A. (2001). The Muturu: A rare sacred breed of cattle in Nigeria. Animal Genetic Resources Information, 31, 27-36. https://doi.org/10.1017/S1014233900001450

Ali, K. F. M. R., Odjoubere, J., Tente, A. B. H., \& Sinsin, A. B. (2014). Caractérisation floristique et analyse des formes de pression sur les forets sacrées ou communautaires de la Basse vallée de l'Ouémé au Sud-Est du Benin. Afrique Science, 10(2), 243-257. Retrieved from http://www.afriquescience.info

Alimi, R. M., Biaou, C., \& Egboou, P. B. (2015). Analyse des dynamiques sociales liées à une gestion apaisée de la transhumance dans la basse et moyenne vallées de l'Ouémé et sa zone d'influence en République du Benin. Rapport d'étude du Réseau de connaissances de la Netherlands Development Organisation (SNV) Afrique de l'Ouest et Centrale sur l'Elevage et le Pastoralisme. Ed IRAM. 79p. Retrieved from http://bj.chm-cbd.net/ressources/suivi-de-la-spanb/axe-strategique-2.-2-preservation-des-ressources-des-eco systemes-et-renforcement/strategique-b/objectif-4/analyse-des-dynamiques-sociales-liee-une-gestion-apaise e-de-la-transhumance/download/fr-BE/1/Analyse\%20des\%20dynamiques\%20sociales\%20li\%C3\%A9es\%2 0a\%20la\%20tranhumance.pdf?action=view

Ayantunde, A. A., Asse, R., Said, M. Y., \& Fall, A. (2014). Transhumant pastoralism, sustainable management of natural resources and endemic ruminant livestock in the subhumid zone of West Africa. Environment, Development and Sustainability, 16(5), 1097-1117. https://doi.org/10.1007/s10668-014-9515-z

Bassett, T. J., \& Turner, M. D. (2007). Sudden shift or migratory drift? Fulbe herd movements to the Sudano-Guinean region of West Africa. Human Ecology, 35(1), 33-49.

https://doi.org/10.1007/s10745-006-9067-4

Blench, R. (1999). Traditional livestock breeds: Geographical distribution and dynamics in relation to the ecology of West Africa. Working paper 122. Overseas Development Institute Portland House Stag Place London, SW1E 5DP

Desta, T. T., Ayalew, W., \& Hedge, B. P. (2011). Breed and traits preferences of Sheko cattle keepers in southern Ethiopia. Tropical Animal Health and Production, 43, 851-856. https://doi.org/ 10.1007/s11250-010-9772-2

Duteurtre, G. (2007). Commerce et développement de la filière laitière en Afrique de l'Ouest : une synthèse. Revue d'Élevage et de Médecine Vétérinaire des Pays Tropicaux, 60(1-4), 209-223. https://doi.org/10.19182/remvt.9972

Felius, M., Beerling, M. L., Buchanan, D. S., Theunissen, B., Koolmees, P. A., \& Lenstra, J. A. (2014). On the History of Cattle Genetic Resources. Diversity, 6, 705-750. https://doi.org/ 10.3390/d6040705

Garoma, S., Ayalew, W., \& Hegde, P. B. (2013). Pastoralists and agro-pastoralists preferences for cattle breed and traits in Fentalle district of East Shoa zone of Oromia, Ethiopia. African Journal of Agricultural Research, 8(45), 5645-5650. https://doi.org/10.5897/AJAR12.764

Kamuanga, M. J., Somda, J., Sanon, Y., \& Kagoné, H. (2008). Livestock and regional market in the Sahel and West Africa. Potentials and challenges. SWAC-OECD/ECOWAS. Paris, France: Sahel and West Africa Club/OECD.

Kugonza, D. R., Nabasirye, M., Hanotte, O., Mpairwe, D., \& Okeyo, A. M. (2012). Pastoralists' indigenous selection criteria and other breeding practices of the long-horned Ankole cattle in Uganda. Tropical Animal Health and Production, 44, 557-565. https://doi.org/10.1007/s11250-011-9935-9

Leroy, G., Baumung, R., Boettcher, P., Scherf, B., \& Hoffmann, I. (2016). Sustainability of crossbreeding in 
developing countries; definitely not like crossing a meadow. Animal, 10(2), 262-273. https://doi.org/10.1017/S175173111500213X

Ministère de l'Agriculture de l'Élevage et de la Pêche. (2002). Rapport annuel de la Direction de l'Élevage, République du Bénin.

Mopaté, L. Y., Kamuanga, M. B., Hamadou, S., \& Kaboré-Zoungrana, C. Y. (2014). Evaluation des pratiques paysannes de conservation in situ du taurin Baoulé au Sud-Ouest du Burkina Faso. Animal Genetic Resources, 54, 171-178. https://doi.org/10.1017/S2078633614000022

Mwai, O., Hanotte, O., Kwon, Y., \& Cho, S. (2015). African indigenous cattle: unique genetic resources in a rapidly changing world. Asian-Australasian Journal of Animal Sciences, 28(7), 911-921. https://doi.org/10.5713/ajas.15.0002R

Mwambene, P. L., Katule, A. M., Chenyambuga, S. W., \& Mwakilembe, P. A. A. (2012). Fipa cattle in the southwestern highlands of Tanzania: morphometric and physical characteristics. Animal Genetic Resources, 51, 15-29. https://doi.org/10.1017/S2078633612000136

Ndiaye, N. P., Sow, A., Dayo, G. K., Ndiaye, S., Sawadogo, G. J., \& Sembène, M. (2015). Genetic diversity and phylogenetic relationships in local cattle breeds of Senegal based on autosomal microsatellite markers. Veterinary world, 8(8), 994-1005. https://doi.org/ 10.14202/vetworld.2015.994-1005

Pazou, E. Y. A., Azehoun, J. P., Aléodjrodo, P. E., van Straalen, N. M., van Hattum, B., \& van Gestel, C. A. (2013). Health risks associated with pesticide residues in sediments, fish, and plants from the Oueme Valley in the Republic of Benin. Archives of Environmental Contamination and Toxicology, 65(2), 260-265. https://doi.org/10.1007/s00244-013-9895-3

Porter, V., Alderson, L., Hall, S. J. \& Sponenberg, D. P. (2016). Mason's World Encyclopedia of Livestock Breeds and Breeding (1st ed.). Vol. 2, 1200. Pack. Cabi. https://doi.org/10.1079/9781845934668.0000

Rege, J. E. O. \& Tawah, C. L. (1999). The state of African cattle genetic resources II: geographical distribution, characteristics and uses of present-day breeds and strains. Animal Genetic Resources Information, 26, 1-25. https://doi.org/10.1017/S1014233900001152

Roschinsky, R., Kluszczynska, M., Sölkner, J., Puskur, R., \& Wurzinger, M. (2015). Smallholder experiences with dairy cattle crossbreeding in the tropics: from introduction to impact. Animal, 9(1), 150-157. https://doi.org/10.1017/S1751731114002079

Sokouri, D. P., Yapi-Gnaoré, C. V., N'Guetta, A. S. P., Loukou, N. E., Kouao, B. J., Touré, G., ... Kouassi, A. (2009). Utilisation et gestion des races taurines locales sous la pression des croisements avec les zébus dans les régions Centre et Nord de la Côte d'Ivoire. Journal of Animal and Plant Sciences, 50(2), 456-465.

Traoré, S. A., Markemann, A., Reiber, C., \& Piepho, H. P. (2017). Production objectives, trait and breed preferences of farmers keeping N'Dama, Fulani Zebu and crossbred cattle and implications for breeding programs. Animal, 11(4), 687-695. https://doi.org/10.1017/S1751731116002196

Wilson, R. T. (2018). Crossbreeding of Cattle in Africa. Journal of Agriculture and Environmental Sciences, 7(1), 16-31. https://doi.org/10.15640/jaes.v7n1a3

Wollny, C. B. A. (2003). The need to conserve farm animal genetic resources in Africa: should policy makers be concerned? Ecological Economics, 45(3), 341-351. https://doi.org/10.1016/S0921-8009(03)00089-2

Wurzinger, M., Ndumu, D., Baumung, R., Drucker, A., Okeyo, A. M., Semambo, D. K., ... Sölkner, J. (2006). Comparison of production system and selection criteria of Ankole cattle by breeders in Burundi, Rwanda, Tanzania and Uganda. Tropical Animal Health and Production, 38, 571-581. https://doi.org 10.1007/s11250-006-4426-0

\section{Copyrights}

Copyright for this article is retained by the author(s), with first publication rights granted to the journal.

This is an open-access article distributed under the terms and conditions of the Creative Commons Attribution license (http://creativecommons.org/licenses/by/3.0/). 